

Copyright: Original content from this work may be used under the terms of the creative commons attributes 4.0 licence.

\section{Eleven Ahmad Pilgrimage And Seal And Flag Of Victory}

Ziyovuddin Muhitdinovich Juraev

Associate Professor Of "Source Studies And Archival Studies", Faculty Of History, National University Of Uzbekistan Named After Mirzo Ulugbek. Doctor Of Philosophy (Phd) In History., Uzbekistan

Oltinoy Masalievna Masalieva

Associate Professor of History of Uzbekistan Uzbek State University of World Languages, Uzbekistan

\title{
ABSTRACT
}

This article examines and analyzes the Eleven Ahmad Shrine and its history from a variety of sources. Another shrine is the Eleven Ahmad Shrine, located in the cemetery in the Yukori Girvon makhalla(neighborhood), Namangan district, on the banks of the Yangiarik River. The land area is 0.59 hectares. In 1991, a new mausoleum dedicated to the Eleven Ahmad was built at the shrine. The area has been landscaped and conditions have been created for pilgrims. These works were built by the locals through hashar.

\section{KEYWORDS}

Eleven Ahmad Shrine, Archaeological excavations, Yukori Girvon, pilgrims.

\section{INTRODUCTION}

This cemetery is very ancient and has not been studied on a scientific basis. Archaeological excavations are needed in its territory.

According to the elders, there was a hill in the village of Girvan, behind which was a large plain, an old maple tree and a spring. Passersby rested under this maple tree, drank from the spring water, quenched their thirst, and then continued on their way.
Union, three strangers pass by here and see the spring. An old man was praying by the spring. The strangers drank the water, then performed ablution and began to pray. When the old man finished praying, he began to recite. His juicy voice, his beautiful recitation enchanted the strangers. Even birds came flying from somewhere and caught the sky. A light rain began to fall. When the reading was over, the rain stopped. 
Three strangers approached him and greeted him politely. They asked him why he was sitting here alone. The old man sighed and began his story: "Brothers, my heart is full. I was a lucky man and lost ten brothers," he said with tears in his eyes. "Ten of my brothers died, and I was left alone in the world." Looks like my day is over too. You did not notice that when I was reciting the Qur'an, Azrael was standing next to me. When the verses of the Qur'an were finished, they disappeared and whispered in my ear that my brothers were calling.

The strangers were astonished. At that moment the sky was covered with a black cloud, and the birds in the sky began to flutter in annoyance. The gushing spring water also stopped. The strangers were stunned and opened their mouths.

They asked the old man why. He said the old man had died, which was a sign of that. At the same time, they announced that they would make predictions about their future lives. Then he turned to the first stranger and predicted that he would become very rich, only to be honest. He predicted to the second that he would be a great merchant, but that he would have to be careful, and to the third that luck would come after his children had grown up, but that the youngest child would grow up rebellious, holding on to his reins.

He then died easily, quoting the word testimony. Look at this, the sky is bright and the sun is shining. Water also began to come from the spring. Within minutes, the stunned strangers regained their sanity. They washed the old man, wrapped him in a shroud, buried him away from the plane tree, and continued on their way. They did not forget this old man close to Allah until his death. Years later, when their prophecies came true, they were blessed again. Thus, the cemetery was named "Eleven Ahmad". There are also many legends about this shrine, all of which are close to each other.
There is also a reserve of sand with healing properties around the shrine, where sick patients can be healed.

Amir Temur Sultan, a great commander who played an important role in the glorious history and development of Uzbekistan, during his reign, strengthened the independence of the kingdom, defeated enemies, built city-states, ensured the security of the kingdom, the welfare of the people and the management of the treasury, strictly adhered to. They relied on God-given, acknowledged spiritual divine support and the power of their descendants. For example, the decisive battle with Qamariddin (1371-72), who put an end to the rule of the Genghis Khans by killing the Mongol khan Ilyaskhodja, took place in the territory of Namangan.

The victorious Sultan Amir Temur erected a victory flag in honor of these Eleven Ahmad on one of the high hills of Namangan. He also built a magnificent mosque and madrasa for the shrine. The buildings in this area have not yet been preserved. It is not surprising that in the late 19th and early 20th centuries, Russian generals led by Rosenbach demolished the Eleven Ahmad Monument, a sign of Amir Temur's potential and a call to fight the Russian invaders. Later, during the years of independence, the people of Namangan changed its location and rebuilt it in a new form at a closer location.

99 names of Allah are mentioned in the Holy Qur'an and Hadith. Abu Mansur Moturidi asSamarkandi wrote about this in his work "Tawhid" with a separate commentary.

In the same way, the Messenger of Allah, may Allah bless him and grant him peace, said that he had 99 names in his honor. The first of these is that Muhammad means to be praised, and the second is that Ahmad means to praise Allah a lot. The third is that "Mahmud" means many praisers. 
For this reason, the famous calligrapher of his time, "Ahmad" came to us through the circular pattern "Hikmat" by Hajikhan . In the middle of it is inscribed: "Hazrat Sultan Khoja Ahmad Yassavi", around which are first decorated the names of the blessed saints of the history of the Prophet, then 9 Ahmad, famous in history. Next to it we see the following Arabic text.

The translation of the text is as follows: "I begin the best of names with the name of Allah. I begin with the name of Allah, the Lord of the heavens and the earth. So I begin with the name of Allah that nothing in heaven or earth can harm because of His name. He is the Hearer, the Knower. "Amali Hajikhan" is written on the engraved letter.

Ibrahim Ota, who lives in the village of Milla Kuding in the Namangan region, has a large engraved seal with the name "Eleven Ahmad" and a genealogy of Ahmad Yassavi's descendants.

The second boulder is a large boulder with the names of the descendants of Ahmad Yassavi's brothers Sadr Khoja.

The first large boulder was split in two and later lost.

The mausoleums built by Amir Temur and the seals and flags of mosques were given to the descendants of Ahmad Yassavi.

Father Abraham said that this seal was given to fifty saints and that three seals have now been found of them, and they exist.

The 11 sheikhs named Ahmad Mubarak in Hikmat, like the descendants of Ahmad Yassavi, are seals specially written for the descendants of the Ahmadis present in it. They lived in different regions and places of Islamic countries, and were recognized as mature sheikhs of the Muslim world due to their services to the religion of Islam and the wise teachings they preached. Because they are known to be true followers of our Prophet Muhammad (saas).

As for the seal bearing the name of Ahmad Yassavi, it is necessary to clarify this blessed inscription on the basis of in-depth research and study. This seal was given to Ahmad Yassavi for his great services to the widespread propagation of Islam and Islam, and after the completion of his mausoleum and an additional new mosque for Muslims by Amir Temur, waqf lands will be allocated for the mausoleum and the mosque. The provision of the mosque is given as an important document for the pilgrims of Ahmad Yassavi (mausoleum) as well as to help the needy people living in the surrounding villages. Special people have been appointed to carry out maintenance work.

But in a number of articles and books by pilgrims and some of our scholars, this seal is referred to as the seal of Ahmad Yassavi. Many books about Sultan ul-Arifin Ahmad Yassavi have been published in Turkey and Arab countries, Afghanistan, India, China (East Turkestan), Central Asian Republics.

These books contain information that the seal was made by Amir Temur and that the tomb and mosque of Ahmad Yassavi were presented by Amir Temur with a flag with Surah al-Fatiha from the verses of the Holy Qu'ran.

The original version of the flag was found by Amir Temur's expedition in the form of a picture and a verse from the Holy Qu'ran inscribed on the flag, as well as an extract from the flag with the name of 11 Ahmad.

Valuable information about Hodja Ahmad Yassavi and his predecessor, the famous scholar and enlightener Sheikh Ahmad, who lived in his time, was scattered in the books. They are: "Muzakkirul Ahbob" by Hasan Khoja Nisari and "Scholars of Sufism" by Hamidjon Hamidi, as well as "Tazkiratul Awliya", "Siroj 
ul-Muslimin" (“Light of Muslims”), "Sultan ulArifin Khoja Ahmad Yassavi" by Hamidkhan Islami, "Eternal life's adornment", "The light of goodness never goes out" by Fakhriddinkhodja Ashrafkhodjaev. Also, in the sources obtained as a result of special research conducted by the "Amir Temur Scientific Expedition", eleven sheikhs Ahmad, written in this seal, have been scientifically, historically and comparatively studied.

There is a shrine "Eleven Ahmad" in Girvan district of Namangan.

In the book "Devoni Hikmat" written by Hazrat Khoja Ahmad Yassavi, they also wrote under different pseudonyms. For example: Miskin Ahmad, Ahmad Yassavi, Turkestani, Khoja Ahmad, Kul Khoja Ahmad, Gharib Ahmad.

We are obliged to quote the notes of Mirahmad Mirkholdor in support of his son's remarks. It is said that Ahmad Yassavi has a tree and a seal in various cities of our region (Shymkent, Republic of Kazakhstan), and even abroad. Especially in recent times, different opinions have been expressed about that famous seal. Some authors try to prove that this is the seal of Khoja Ahmad Yassavi, in which the 11 sheikhs named are different nicknames of Khoja Ahmad Yassavi.

We have found it necessary to clarify this issue concerning our great compatriot, Sheikh-ulMashayikh Khoja Ahmad, to put an end to the confusion, and we have attached the following to you, dear ones! As far as we know, that famous seal belongs to the mausoleum of Ahmad Yassavi, in which the names of Sheikh Ahmad mentioned are pure people who lived before and after our great compatriot. So who are the eleven Sheikh Ahmads in the seal? We find the answer to this question, first of all, in the pages of the "Chor Kitab" written two centuries ago. The information given about Yazdah Ahmad contains the names of the Eleven Ahmad mentioned in this seal, and it is said that there will be many blessings for those who remember these saints. The names of the Eleven Sheikh Ahmad in this seal are also mentioned in the book in the same Arabic inscription, almost one by one.

Thanks to independence, our compatriots have written many books about the great Khoja Ahmad Yassavi. But that's still a little. However, hundreds of books have been published in Turkey about Sultan ul-Arifin Hodja Ahmad Yassavi. Our history has changed a lot due to the repressions and antireligious struggles of the last century. Superficial views of history still prevail. For a long time, some writers and historians have been writing the old seal, which has been preserved in the hands of the descendants of Hazrat, as the "seal of Khoja Ahmad Yassavi", and this misconception still persists.

Below we will try to clarify who the Eleven Ahmads mentioned in this seal are structurally and from which countries, and who they are. In particular, they lived in the lands of Arabia, Syria, Baghdad, Herat, Samarkand, Bukhara, Turkestan. They are:

Prophet Muhammad (saas) was born in Mecca, 570-632 AH. Sheikh Ahmad Hanbal (d. 855) was the founder of Hanbali, one of the Sunni sects of Ahl as-Sunnah wa'l-Jama'ah, now Syria. Sheikh Ahmad Khair Nassoj (lived 127 years. Died 946) - Baghdad. Sheikh Ahmad Arqam - (?). Sheikh Ahmad Khuzrawiyah lived in Balkh in the late eighth and first quarters of the ninth centuries. Sheikh Ahmad Ravviyya (Rovanda) (died in the early 10th century, at the age of 80) was a theologian who lived in Baghdad. Sheikh Ahmad Mukhtar (died 899). The tomb is in Herat. Ahmad Jam (?) is a mature theologian from Samarkand. Sheikh Ahmad Kabir (died 832) was a jurist living in Bukhara. Sheikh Ahmad Saghoriyya is a jurist on agriculture. He lived in Bukhara. Sheikh Ahmad Yassavi (died 1161) - Sheikh ulMashayikh Sultan-ul-Arifin, Qutb ul-Aqtab of 
Turkestan. We will try to give a brief information about the author of the book "Devoni Hikmat".

According to the above research, that famous seal of "Wisdom" belonged to the mausoleum of Ahmad Yassavi, in which the mentioned Sheikh Ahmads - the descendants of those who lived before our great compatriot turned out to be pure. They are:

1. At the beginning of the list of eleven Ahmad is written Ahmad Mursal - the Messenger of Allah, the Great Creator of our Prophet Muhammad (saas). We all know that the Almighty Muhammad (peace be upon him) (570-632) was born in Mecca, his father was Abdullah, his ancestors were Abdumutalib, Abduhoshim, Abdumannof, and his mother was Amina. Even the high fathers of our Prophet (saas) go back to Ibrahim Khalilullah. From him goes to Adam Alaihis Salam.

The scholars say that whoever claims to be a Muslim should know the Prophet Muhammad (peace and blessings of Allah be upon him) as if he knew his parents. The Prophet (peace and blessings of Allah be upon him) himself was from the tribe of Quraysh, the tribe of Bani Hashim, of Arab descent, and his name was Muhammad Mustafa (peace and blessings of Allah be upon him). As it is emphasized in the great books, it is a great blessing to know and respect our Prophet (saas), his descendants, his Companions and his scholars.

The kindness of the Prophet (peace and blessings of Allah be upon him) to our ummah, the transmission of the Qur'an revealed by Allah, his concern for his ummah, his asking for mercy and blessings from Allah, and his good manners and activities will not be forgotten until the Day of Resurrection.

It is known that great books have been written about the biography and portrait of
Mursal Ahmad (sallallaahu 'alayhi wa sallam), so we have summarized our writing here.

Since the blessed rites of the Prophet Muhammad, may Allah bless him and grant him peace, were predicted to be the place where all wishes and requests will be fulfilled, a special pilgrimage will be performed there. In the presence of the Blessed Prophet, Allah will be asked what his wishes are, and on behalf of his relatives, recitations, good wishes, greetings and blessings from the verses of the Qur'an will be delivered to our Prophet. In the same way, in the holy mausoleums and shrines of the beloved servants of Allah, the same deeds and wishes must be expressed sincerely.

Otherwise the corpse in the grave will suffer. In order to forget Allah by asking for help from the corpses lying in the graves, we must not unknowingly turn ourselves into polytheists, treat the corpse as a means of polytheism, fall into sin, and torment the corpse and ourselves.

Now, for the sake of goodness, the saints who have attained a high position in the past through their hardships, when they visit the friends of Allah, to learn a lesson, to be cleansed of sins, to turn away from evil, to step towards goodness, are allowed to do good deeds. must follow the etiquette of pilgrimage to the extent that he gives.

If the eleven Ahmad, as one of the purest places where the supplications and supplications of man and people are accepted, know that they are from the respect of their owners, then they should observe the rules of pilgrimage and follow the rules that gave them Islamic law, they must not forget that the meaning here is a place to learn, a means to an end. Because everyone comes to the pilgrimage to be purified, to come in clean clothes and to receive the blessings of Allah. 
2. Sheikh Ahmad Hanbal - (died 855). Founder of the Hanbali sect in Sunni Islam, theologian. He studied in Baghdad. Ahmad Hanbal Shari'a sources: The Qur'an, hadith, sunnah and ijma', alliance, ray, condemn any news that is not based on comparison. He was the keeper of the words of the Prophet Muhammad (saas). He was a leading imam of his time, a faqih, a scholar. He collected thirty thousand hadiths from the Prophet (saas) and wrote a sixvolume book called Al-Musnad.

3. Sheikh Ahmad Khair Nassoj - Sheikh Ahmad Khair Nassoj went to find and return lost animals, people and property. Sheikh Ahmad Khair Nassoj was one of the famous Ahmadis whose names were inscribed on the Hikmat seal. He was the one who explained the issues of Baghdad, the Sheikh of the time, the "best of the best", and morality in narrations. This man made a living as a weaver. He lived 127 years. He died in 946.

4. Sheikh Ahmad Arqam - They went to Sheikh Ahmad Arqam to achieve economic perfection. Sheikh Ahmad Arqam was a man of sharp discovery and prophecy. He prophesied that the city of Osh would be a building, where he died. His name was written on the seal. So, these great saint Ahmad, were among the sheikhs who, by the grace of Allah, helped to solve the problems that came to the people and to rewarded them.

5. Sheikh Ahmad Khuzrawiyah - Whoever needs a position and glory needs to go to Sheikh Ahmad Khuzrawiyah. Ahmad Khuzrawiyah was one of the sheikhs who lived in Balkh in the late eighth century and the first quarter of the ninth century. He interviewed and learned from Abu Turab Nakhshabi, Ibrahim Adham, Yahya Maoz, and Hotam Asim. Ahmad Khuzrawiyah visited Mecca and Medina several times. During one of his pilgrimages, he visited the cities of Nishapur and Bistam, where he benefited from the blessed breaths of the famous sages Abu Hafs
Haddad and Boyazid Bistami. Ahmad achieved an unparalleled career in the field of mercy.

According to Fariduddin Attar's Tazkirat ulAwliyya, the sheikh always wore a military uniform. Muhammad Siddiq Rushdie writes: Ahmad Khuzrawiyah had a thousand murids, "each of them was able to walk on water and fly on air, and he had many conversations with Abu Talib Nahshabi, the murid of Hotam Asim." Sheikh Abulhafz said, "Ahmad Khuzrawiyah was the highest of them all." Ahmad Khuzrawiya married Fatima, the daughter of the governor of Balkh, and she too joined the sect.

6. Sheikh Ahmad Ravviyya (Rovanda) - People who wanted to become scholars in search of knowledge went to Sheikh Ahmad Ravviyya. Sheikh Ahmad Rawwiya was a theologian living in Baghdad. He wrote more than forty works on theology, rejecting the teachings of the Mu'tazilites. He died in the early tenth century, at the age of 80 .

7. Sheikh Ahmad Mukhtar - (died 899) Qutb ulMashayikh, a scholar of the teachings and the truth, was buried in Herat. It is said that he spent his nights awake because of his passion for Allah.

8. Ahmad Jam - This mature person must be from Samarkand. Islamic sciences: The exegesis of the Qur'an, the perfect scholar in the enlightenment of the Hadith, the rules of the Shari'a, the leader of the sciences of jurisprudence in his time. Nurabad district of Samarkand region ranks second in the Republic of Uzbekistan in terms of location and size after the village of Almaz in Chust, Namangan region. There were many scholars and saints who grew up there.

9. Sheikh Ahmad Kabir - Those who want a child go to visit Sheikh Ahmad Kabir. Sheikh Ahmad Kabir was a noble saint, jurist, scholar. He lived in Bukhara, Sheikh-ush-Shuyukh, Waliullah (died 832). 
10. Sheikh Ahmad Saghori - Goes to Sheikh Ahmad Saghori for the development of agriculture and for the trade bar. Sheikh Ahmad Kabir's son, Ahmad Saghori, was a saint, a guardian, a jurist, a pious scholar. He worked hard in Bukhara and established peace.

11. Sheikh Ahmad Yassavi - People go to Sheikh Ahmad Yassavi shrine to remember the spirit, health and happiness of their parents. Khoja Ahmad Yassavi - Sheikh ul-Mashayikh, Sultanul-Arifin, Qutb ul-Aqtab of Turkestan. In the wisdom of Yassavi, the meanings of the Qur'an, the rules of Islamic law and the propagation of the fundamentals of the sect, the subject of divine love, good morals, and the education of the soul are interpreted as perfect Muslim virtues. The world-famous book "Devoni Hikmat" by our great compatriot remains one of the programs in our lives.

It should also be noted that great books have been written about each of these famous eleven sheikhs, and many more are still being written. We will continue to study their most virtuous lives as role models for humanity.

\section{CONCLUSION}

From the above information, it is clear that the eleven Ahmad in the famous seal are not the nicknames of Ahmad Yassavi, as some Uzbek, Kazakh, Russian and other scholars have written, but the devotees of knowledge and enlightenment who lived before and after him and served Islam. This seal was made by the order of Amir Temur after the construction of the mausoleum of Khoja Ahmad Yassavi.

As Mirahmad Mirkholdor oglu said, we hope that scholars, writers and translators will take into account the more detailed final conclusion in the future.

\section{REFERENCES}

1. Munavvarov, Z., \& Jo'rayev, Z. (2018). ALMAWARDI'S WORK “AL-AHKAM ASSULTANIYYA WA-L-WALAYAT ADDEENIYYA" -AS AN ESSENTIAL SOURCE ON THE HISTORY OF STATEHOOD IN THE MUSLIM WORLD. The Light of Islam, 2018 (1), 3.

2. Jo'raev, Z. (2013). POLITICAL AND LEGAL DOCTRINE OF THE EASTERN STATE GOVERNANCE OF MOVARDIY - STUDY OF THE WORK "AHKOM". Society and Management, (1).

3. Juraev Ziyovuddin Muhitdinovich. (2020) AL-AHKOM AS-SULTANIYA VA-LVALOYOT AD-DINIYYA IN SOURCE CLASSIFICATION OF WORLD MANUSCRIPTS STUDY OF ABULHASAN MAVARDI PRODUCT. Journal of Critical Reviews, 7 (3), 438-450. doi: 10.31838 / jcr.07.03.82

4. Masalievna, M. O. (2017). LOCAL HISTORIOGRAPHY OF BUKHARA EMIRATE AT THE END OF NINETEENTH AND EARLY TWENTIETH CENTURIES. Himalayan and Central Asian Studies, 21 (4), 39.

5. Straupeniece, D., \& Choriev, S. (2020). Ethnoculture of The Baltic Nation In Turkestan (1867-1917yy.). The American Journal of Interdisciplinary Innovations and Research, 2(10), 40-52.

6. Чориев, Ш. Ш. (2016). Из истории формирования фондов государственных органов Туркестанской АССР. Документ. Архив. История. Современность.Екатеринбург, 2016, 209-212.

7. Nazarov, A. Y. (2020). Scientific societies in the Turkestan governorate-general as an instrument of colonial statehood (archival source study). Journal of Critical Reviews, 7(7), 1068-1073.

8. Nazarov, A. (2020). History Of The Emergence And Development of Scientific Societies In The GovernorGeneral of Turkestan. The American Journal of Social Science and Education Innovations, 2(10), 82-88. 
9. Juraev, Z. M. (2019). THE INTENTION-A CHOICE OR THE DOCTRINE OF ELECTION IN MAVARDI PRODUCT" A L-AHKOM-ASSULTONIYA VA-L-VALOYOT AD-DINIYA". Theoretical \& Applied Science, (7), 446453.

10. Masalievna, M. O. (2017). LOCAL HISTORIOGRAPHY OF BUKHARA EMIRATE AT THE END OF NINETEENTH AND EARLY TWENTIETH CENTURIES. Himalayan and Central Asian Studies, 21(4), 39.

11. Masalieva O. (2020).The role of Russian scientists in the source study of the Bukhara Khanate. International Journal of Advanced Science and Technology. 29/5. pp. 1540-1546

12. Juraev Z. M., Masalieva O. M. The Illumination of Bukhara Khans' Building Enterprise in the Some Historical Sources. TEST.Engineering and management. 83. Pp. $1803-1811$ 